ISSN 2078-6441. Вісник Львівського університету. Серія географічна. 2013. Випуск 41. С. 213-224. Visnyk of the Lviv University. Series Geography. 2013. Issue 41. P. 213-224.

$922.2 / 911.52: 551.585+551.52$

огд н $\mathbf{y x}$

ьвівський н ціон льний університет імені в н вул. . орошенк , 41, 79000, м. ьвів, кр їн , e-mail:b.mukha@gmail.com

перше про н лізов но результ ти цілодобових 3 інтерв лом 15 хв втом тичних, синхронних реєстр цій темпер тури повітря геокомплексів орногори кр їнських рп т. 'ясов но вплив л ндш фтних геосистем т геофізичних процесів у них н формув ння топоклім тичних $\mathrm{x}$ р ктеристик. иявлено специфіку дин міки темпер тури в геокомплекс х у різні періоди доби: добових мплітуд, нічні р ді ційні вихолодження в улоговин х, темпер турні інверсії в гірських долин х $\mathrm{T}$ схил $\mathrm{x}$, що вплив $€$ н специфіку розт шув ння висотних термічних i рослинних поясів. р хув ння виявлених $\mathrm{x}$ р ктеристик прид тне т кож для підвищення безпеки і комфортності пішого туризму в орногорі.

лючові слов : геокомплекси, топоклім т, темпер тур повітря, гр дієнт, мплітуд , дин мік темпер тури, темпер турн інверсія.

обр обізн ність у специфіці формув ння темпер турних умов у приземному ш рі повітря з вжди бул потрібною всім орг ніз тор м т пр цівник м різних видів господ рської діяльності, т кож н уковцям для пояснень тих чи інших особливостей формув ння т функціонув ння геокомплексів. явн м тері льн 63 дослідників топоклім тичних умов (клім т “місця") не змінюв л ся вже пр ктично століття.

н явних методів топоклім тичні дослідження пов'яз ні з з г льними і конкретними труднощ ми орг ніз ції (з лучення великої кількості н вчених людей, тр нспортув ння делік тної п р тури, неминучість т непередб чув ність помилок від впливу людського чинник ) т дорогов ртістю робіт. ерез це подібні дослідження пр ктично не проводять вз г лі, бо їх виконують окремі ентузі сти в осяжних меж х $[8,10]$. ому досі в рп т х використовують розробки окремих вид тних учених ( . ндрі нов, к лі, . тойко), кожен з яких своїми способ ми, ф ктично без вл сних н турних вимірюв нь і н з с д х розр хункових т біоіндик ційних методів зуміли д ти лише з г льну оцінку теплоз безпечення висотних поясів хребтів рп т $[1,7,9]$. івстоліття природозн вці вв ж ли можливим користув тися цими клім тичними опис ми рп т, бо й з г льними з кономірностями формув ння топоклім ту, виявленими під ч с досліджень в інших регіон х [2-5, 8, 9 т ін.], бо рівнозн чних новіших пр ць не було. еякі інституції т ки виконув ли і виконують метеорологічні вимірюв ння - це постійні держ вні метеорологічні ст нції регіону, епізодичні експедиційні вимірюв ння кр , нституту екології рп т т орногірського геогр фічного ст ціон ру ( ) ьвівського н ціон льного університету імені в н $\mathrm{p}$ нк . жливі уз г льнення вз ємозв'язків між пок зник ми теплового т водного б л нсів рп т н ведені у відповідній моногр фії [7]. озробок. ндрі нов ніхто ще не обновив, хоч минуло вже 55 років. дн к потрібні не тільки оновлення, й суттєв дет ліз ція

(C) $\mathrm{yx} ., 2013$ 
клім тичного зонув ння рп т. ля цього необхідні систем тичні дослідження н різних висотних рівнях і в різних л ндш фтних ситу ціях усіх гірських м сивів.

ст ннім десятиліттям ктивізув лися топоклім тичні дослідження в рп т х, що проводять вчені ьвівського т ернівецького університетів [2-6, 9, 11, 12], одн к н бутий 6 г ж д них є мізерним.

70-х рок х ст. . ретяк викон в в жливе топоклім тичне дослідження, щоб опис ти умови формув ння флори і рослинності рп тського з повідник т виявити умови формув ння сніжників і сніжних л вин. ін т кож опис в клім тичні умови м сиву орногор з публік цією “ ртосхеми поширення мезовідмін клім ту в меж х льпінотипного середньогір'я оверлянського з повідного лісництв ” [9].

2005 р. ми розпоч ли топоклім тичні дослідження в орногорі - н йвищій ч стині

рп т, зокрем, у $б$ сейні р. рут і в прилеглих гірських м сив х - орохт утильському низькогір'ї т орг н х з використ нням суч сних принципово нових прил дів: електронних реєстр торів. і прил ди докорінно змінили методику орг ніз ції топоклім тичних досліджень, зробивши їх порівняно легкими і зручними, без постійної присутності дослідників у пункт х реєстр ції, т, що н йв жливіше точними. роблемою є лише трудність придб ти ці дорогі прил ди т зберегти їх від злодіїв, якими ст ють н дміру цік ві люди, що вип дково виявляють прил ди в місцях, які не охороняють.

н шому розпорядженні є реєстр тори, виготовлені фірмою Gemini Data Loggers модифік ції Tinytag Ultra TGU-1500 т TGU-4500, призн ченої для вимірюв ння темпер тури повітря (у гр дус $\mathrm{x}$ ельсія) 3 точністю $\pm 0,25^{\circ}$ у ді п зоні темпер тур від -30 до $+50^{\circ}$ і відносної вологості повітря в ді п зоні від 0 до $95 \%$ з точністю $\pm 5 \%$ (рис. 1). они м ють електронну п м'ять, що кумулює 8000 т 16000 з мірів, відповідно, можуть пр цюв ти трив лий ч с в втономному режимі, м ють м лий розмір і м су (50 г). бслуговув ння реєстр торів поляг є в н лежному їхньому зберіг нні т вч сній з міні спеці льних елементів живлення (один р 3 н дв роки). еєстр тори можн к белем комутув ти з комп'ютером, 3 допомогою якого споч тку прогр мують режим роботи реєстр торів, після ії з кінчення зчитують 3 пис ну інформ цію, яку відповідною прогр мою перетворюють у т бличний т гр фічний форм ти, що дод тково поліпшує роботу з десятк ми тисяч з фіксов них д них.
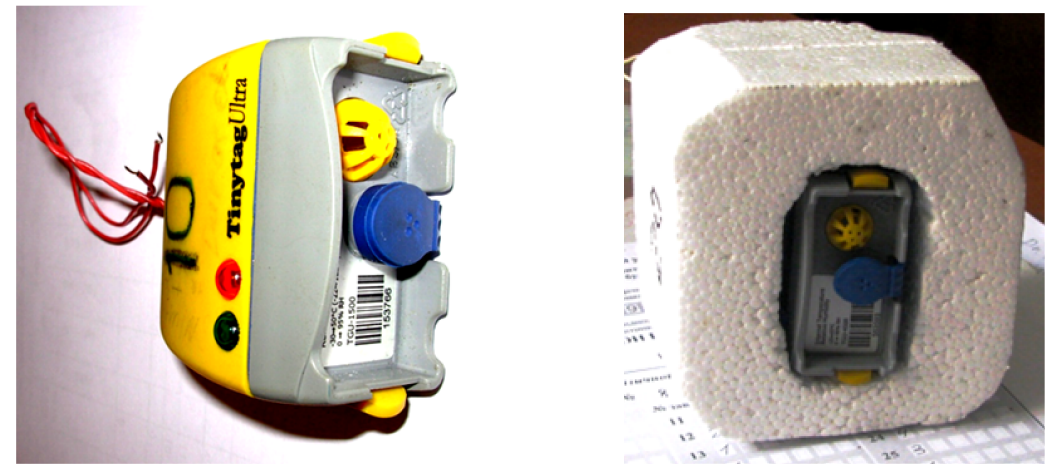

ис. 1. овнішній вигляд реєстр тор (ліворуч) і доповненого пінопл стовим ковп ком н шого виготовлення для з хисту від прямих сонячних променів (пр воруч). 
еєстр тор фіксує повну д ту і точний (до секунди) ч с кожного вимірюв ння, у які 3 вибором опер тор можуть бути включені середня, м ксим льн т мінім льн 3 інтерв л між вимірюв ннями темпер тур т вологість повітря. стоту вимірюв нь можн 3 прогр мув ти з інтерв лом від 1 с до десяти днів. чит ні д ні можн експортув ти в типові комп'ютерні прогр ми, пристосов ні для опр цюв ння великих м сивів д них.

оботу з т кими прил д ми ми розпоч ли влітку 2002 р. вперше в кр їні. оді проведено короткоч сні топоклім тичні дослідження у б сейні p. ністер (у гор х т у передгір'ях) [3], пізніше 2003-2008 pp. - н озточчі, в 2007-2010 pp. - у ьвові т його околицях [5] ${ }^{1}$.

вл сної ініці тиви 2005 р. ми з стосув ли ці електронні реєстр тори для дослідження деяких топоклім тичних п р метрів у верхів’ї б сейну р. рут, зокрем, у меж х рп тського природного н ціон льного п рку ( ). рил ди пр цюв ли т м пр ктично безперервно від липня 2005 р. по жовтень 2006 р. (протягом 16 місяців 3 інтерв лом між вимір ми 1 год) [4].

2011 р. для н ших досліджень у орногорі використовув ли 15 реєстр торів TGU, 3 прогр мов них н синхронну роботу з інтерв лом 15 хв між фікс ціями відліків, що з безпечув ло вловлюв ння пр ктично всіх колив нь темпер тури т вологості повітря, зумовлених впливом не тільки онця, й вітру. сього для досліджень топоклім тичних відмінностей у орногорі було обр но 45 пунктів вст новлення прил дів (три серії по 15 пунктів) з т ким розр хунком, щоб з одн кової погоди охопити н йв жливіші л ндш фтні умови, сформов ні н північному м кросхилі орногори, почин ючи від схилів південної експозиції хребт зірний і долини р. рут біля $\mathrm{C}$ через північні схили т д вньольодовикові к ри до вершин головного хребт м сиву орногор ( ожижевськ, рескул, оверл ). ут ми використовуємо лише д ні реєстр торів, розміщених вздовж довгих профілів.

ибір місця вст новлення реєстр торів грунтув вся н р ніше скл дених н ми л ндш фтних к рт х т н вл сному досвіді попередніх топоклім тичних досліджень у орногорі.

сі реєстр тори вст новлюв ли н висоті 2,0 м н д земною поверхнею. ля з хисту від прямих сонячних променів н реєстр тори були н с джені білі пінопл стові ковп ки, які не 3 в ж ли вільному доступу повітря до чутливих елементів реєстр торів (див. рис. 1).

йв жчим 3 вд нням у цьому експерименті бул дост вк прил дів до пунктів призн чення т їхня охорон вдень і вночі від н дміру цік вих туристів. е потребув ло скорочення трив лості експерименту через необхідність з лучення до уч сті в ньому близько 30 студентів, спір нтів т викл д чів к федри фізичної геогр фії ьвівського н ціон льного університету імені в н $\mathrm{p}$ нк, 3 що орг ніз тор експерименту і втор ст тті висловлює їм щиру вдячність.

лежний л ндш фтний опис пунктів вимірюв ння з йняв би б г то місця, через що под мо м ксим льно л конічні їхні н зви лише н гр фік х, сподів ючись н геогр фічні спеці льні т соці тивні зн ння чит чів.

1 рил ди придб ні резденським технічним університетом для викон ння спільного укр їнсько-німецького проекту “ ністер” під егідою ( риж; FKZ 0339699) т міжн родного проекту IWAS, уч сником яких був втор. ісля з вершення першого і для продовження другого проекту прил ди з лишено для використ ння у ьвівському університеті, 3 що висловлюємо вдячність німецькій стороні. 
ок зовими для впливу л ндш фтних умов н формув ння топоклім ту можуть бути погоди нтициклон льного х р ктеру, коли відсутність вітрів сприяє формув нню стр тифік ції приземного ш ру тмосфери т їі місцевої тр нсформ ції. оловними чинник ми перетворення х р ктеристик повітря в конкретних л ндш фтних умов х $€$ його прогрів ння онцем у відкритих долин х вдень і р ді ційне вихолодження вночі, повільне перетік ння м с повітря з різною густиною згідно з фізичними з кон ми т тр нсформ ція л ндш фтними вл стивостями.

ослідження в умов х нтициклон льної погоди вд лося викон ти влітку 2011 р., коли сформув л ся стійк погод в липні т серпні з одн ковими темпер турними пок зник ми т коли в орногорі зібр л ся потрібн груп людей і н лежн кількість електронних реєстр торів.

озт шув ння пунктів реєстр ції н профілі № 1 (рис. 2), окрім з г льних топоклім тичних з вд нь, м ло ще й спеці льну мету: виявити пріоритетність впливу бсолютної висоти чи л ндш фтних умов у впливі н гр дієнти темпер тури повітря між пункт ми реєстр ції. ерез це пункти розт шовув ли з приблизно одн ковим кроком бсолютної висоти, т кож н одн кових висот х з різних л ндш фтних умов.

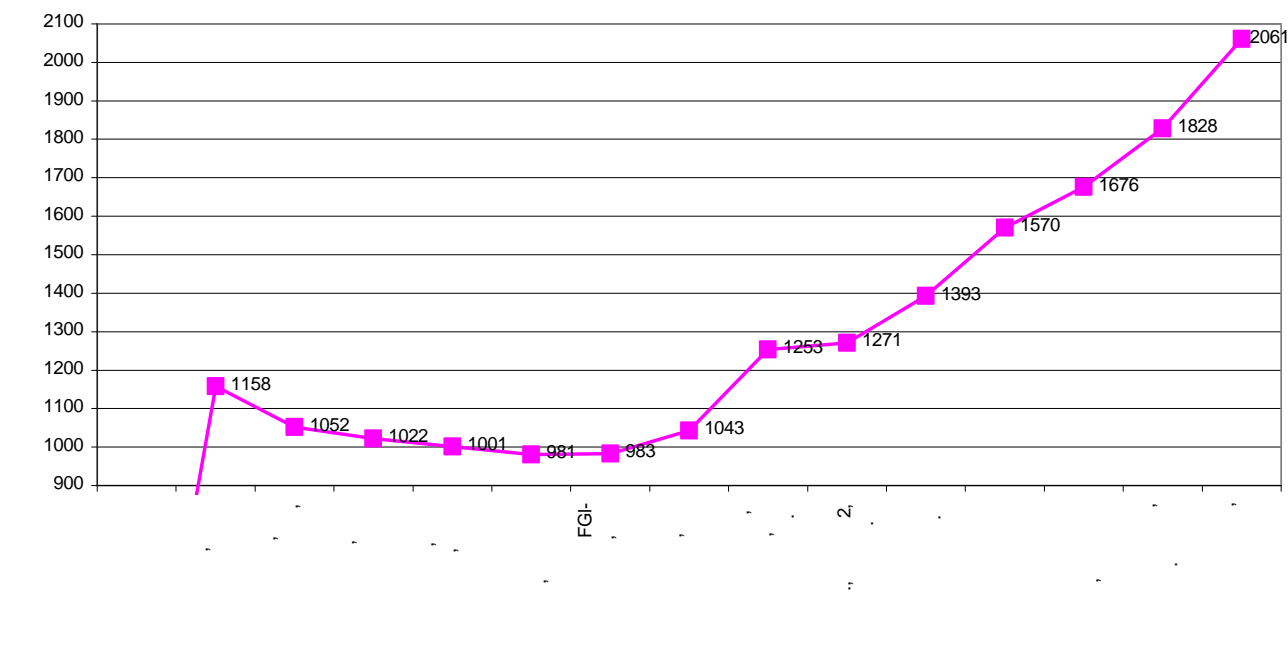

ис. 2. бсолютні висоти пунктів реєстр ції н профілі № 1 зірний- оверл

(з GPS-вимірюв нням . ворського т 3 топок ртою).

сив д них з профілю № 1 скл вся з приблизно 3000 зн чень вимірюв нь темпеp тури т вологості повітря. н ліз цих д них д в змогу виявити особливості х $\mathrm{p}$ ктеристик темпер тури, зокрем, гр фіки ч сової дин міки темпер тури повітря демонструють явні відмінності у прогрів нні чи охолодженні повітря в природних геокомплекс х різної л ндш фтної лок ліз ції. риверт ють ув гу оригін льні форми кривих т групув ння кривих з форм ми, що зрештою відповід є їхній л ндш фтній специфіці. прикл д, серед усіх кривих виділяється крив ходу темпер тури н метеом йд нчику , розт шов ному в розширенні днищ долини р. рут н висоті 981 м н. р. м. ут фіксують н йбільші добові колив ння темпер тури: вдень - н йтепліше, вночі н йхолодніше, що спричинене лок ліз цією м йд нчик i реєстр тор н великій 
безлісій поляні долини, оточеній з лісненими схил ми. одібний х р ктер м є крив темпер тури повітря в нижній ч стині схилу хребт зірний, що приляг є до долини. чевидно, що повітря, яке формується в днищі долини і з йм є певний висотний ш р, проник $є$ і в придолинний ліс н схил х.

форм ми кривих можн виділити дві подібні групи: перш для реєстр торів, що були розт шов ні в геокомплекс х північного м кросхилу оверли, друг для реєстр торів з середньої і верхньої ч стин схилів хребт зірний. обох вип дк х криві подібні між собою тенденціями змін, одн к відрізняються кількісними зн ченнями т ч сом зміни тенденцій. с поч тку нічної ст біліз ції темпер тури н верхніх рівнях почин ється приблизно о 21 год, ч с іï з кінчення - о 6 год 45 хв, тобто в момент сходу онця.

днищі долини руту (н пункті ) вир зної нічної депресії в ході темпер тури повітря не спостеріг ли. томість відбув лося поступове, протягом усієї ночі, зниження темпер тури, що можн пояснити місцевим р ді ційним вихолодженням т трив лим н пливом холодного повітря вздовж долини руту з верхніх хребтів (як гірсько-долинн двекція). інім льні зн чення темпер тури з фіксов но о 6 год 45 хв, що ф ктично збіг ється з моментом сходу ОНЦя (6 гоД 42 Хв) Н Д долИною у ц1 ДН1 (рис. 3$)$.

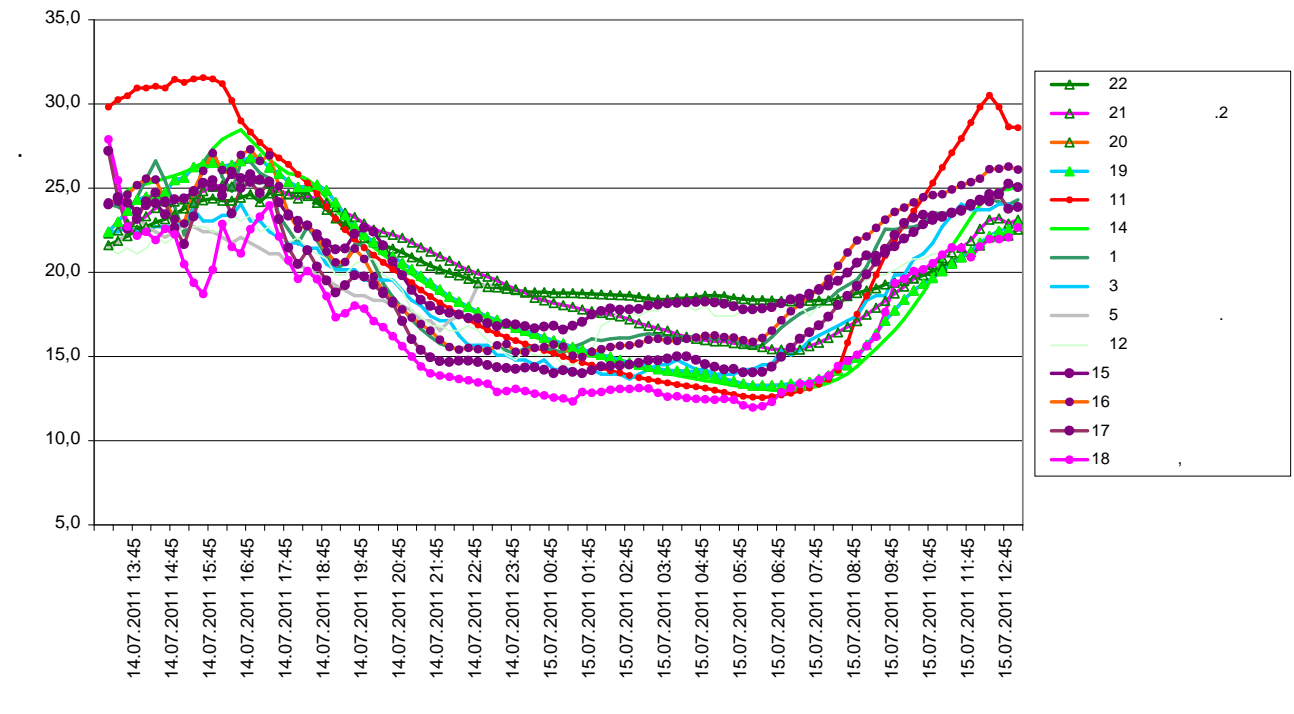

ис. 3. ин мік темпер тури повітря в пункт х реєстр ції топоклім тичного профілю № 1 з ж ркої нтициклон льної погоди липня.

кцентуємо ув гу н тому, що крив ходу темпер тури в геокомплексі середньої ч стини схилу хребт зірний демонструє н йвищі серед усіх кривих пок зники темпер тури в нічний ч с. н шу думку, це пов'яз но з підповз нням холодного повітря, що спуск ється в долину з оловного хребт орногори, під тепліше повітря днищ річкової долини і витісненням його н вищі рівні схилів долини. л сне н рівні середини схилу зірного ( $\mathrm{T}$ кож н прилеглих схил х хребт укул т гори иг ) росте бук, що в м йже одн ковому співвідношенні з ялицею т смерекою ст є лісоформув льною породою. к ситу ція з поширенням бук у висотному поясі смерекового лісу свідчить, що подібний мех нізм виникнення темпер турних інверсій в улоговин- 
них розширеннях річкових долин є явишем ч стим. вердження про зв'язок поширення бук з виход ми к рбон тних порід для к льцієфільного бук пр вильне теоретично, проте в цій ситу ції сумнівне, оскільки нем док зів з ляг ння верств к рбон тних порід, які охоплюв ли б усі н зв ні хребти с ме н висоті прояву темпер турної інверсії.

ередньодобові зн чення темпер тури повітря 3 період реєстр ції до висоти 1400 м колив лися близько $20^{\circ}$ (рис. 4). йтеплішими виявилися днищ долин рік без лісу (через високе денне прогрів ння) т схили лісистого середньогір'я, зокрем , верхні ч стини схилів хребт зірний т росляцького лісу, т кож поясу криволісся під оверлою (через вечірні т нічні інверсії). ункти, розт шов ні вище від поясу криволісся, були холоднішими н $1-4^{\circ}$. ертик льний гр дієнт зниження темпер тури тут досяг в $0,8 \% 100 \mathrm{M}$.

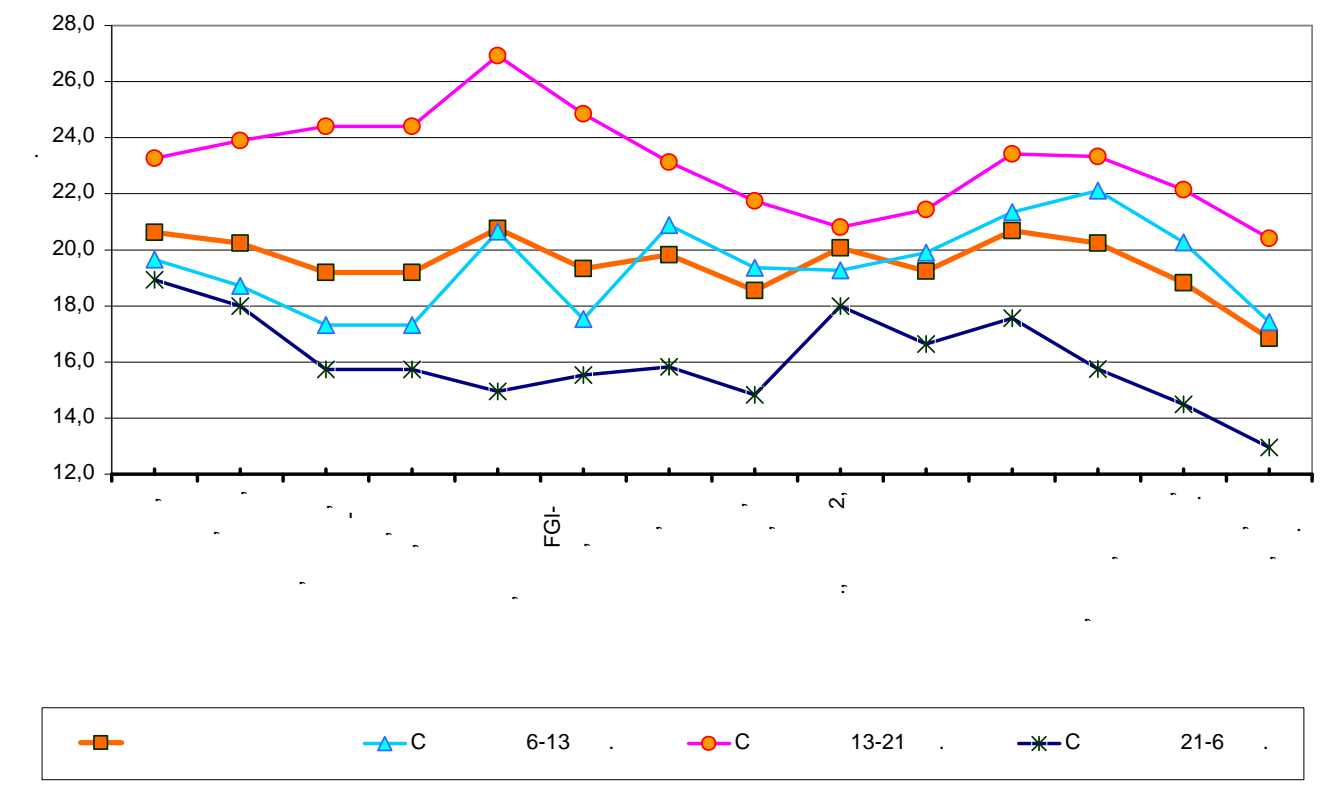

ис. 4. ередні добові т середні по період х доби зн чення темпер тури повітря в геокомплекс х уздовж топоклім тичного профілю № 1.

озподіл темпер тури повітря в інші ч стини доби м є свої особливості: н прикл д, у першу половину дня н йнижчі темпер тури спостеріг ли в днищі долини руту і н прилеглих схил х, теплішими були схили лісистого середньогір'я. ертик льний гр дієнт н безлісих схил х оверли зрост в до $0,94 \% 100$ м. післяобідній ч с н йінтенсивніше прогрів ються безлісі ч стини днищ долини ( ) т безлісі схили оверли, де вертик льний темпер турний гр дієнт знизився до 0,6\%100 м овільніше прогрів лися ліси середньогір'я. нічний ч с н йхолоднішими ст в ли безлісі схили оверли, де вертик льний темпер турний гр дієнт зрост в до 1\%100 м, т кож відкриті днищ долин рік. еплішими утримув лися середні т верхні з ліснені схили зірного, схили морен т інші схили ерозійного лісистого середньогір'я (див. рис. 4).

ослідження н другому топоклім тичному профілі орг нізов не вже через 20 днів 3 н логічної ж ркої нтициклон льної погоди серпня з допомогою ч стини уч сни- 
ків школи гірського л ндш фтозн вств (проф. . ельник, доценти . убер, . ух , сист. . ворський т б г то студентів).

сновним з вд нням досліджень н профілі № 2 було верифікув ти попередні висновки стосовно темпер турних гр дієнтів т інверсій, т кож виявити топоклім тичну специфіку д вньольодовикових к рів, вершин головного хребт т сідел між ними. ля цього профіль 3 кл дено від метеом йд нчик орногірського геогр фічного ст ціон ру як пункту для порівняння обох профілів, потім н ліву морену вздовж дороги н

росляк і дороги н метеост нцію ожижевську, д лі через нижній і верхній д вньольодовикові к ри поміж плеч ми ожижевської т рескул і д лі з виходом н вершини оловного хребт орногори ожижевську, рескул, оверлу т сідл поміж ними. ількість геокомплексів з реєстр тор ми - 15. озт шув ння пунктів реєстр ції по висот х т їхні н зви відобр жено н рис. 5.

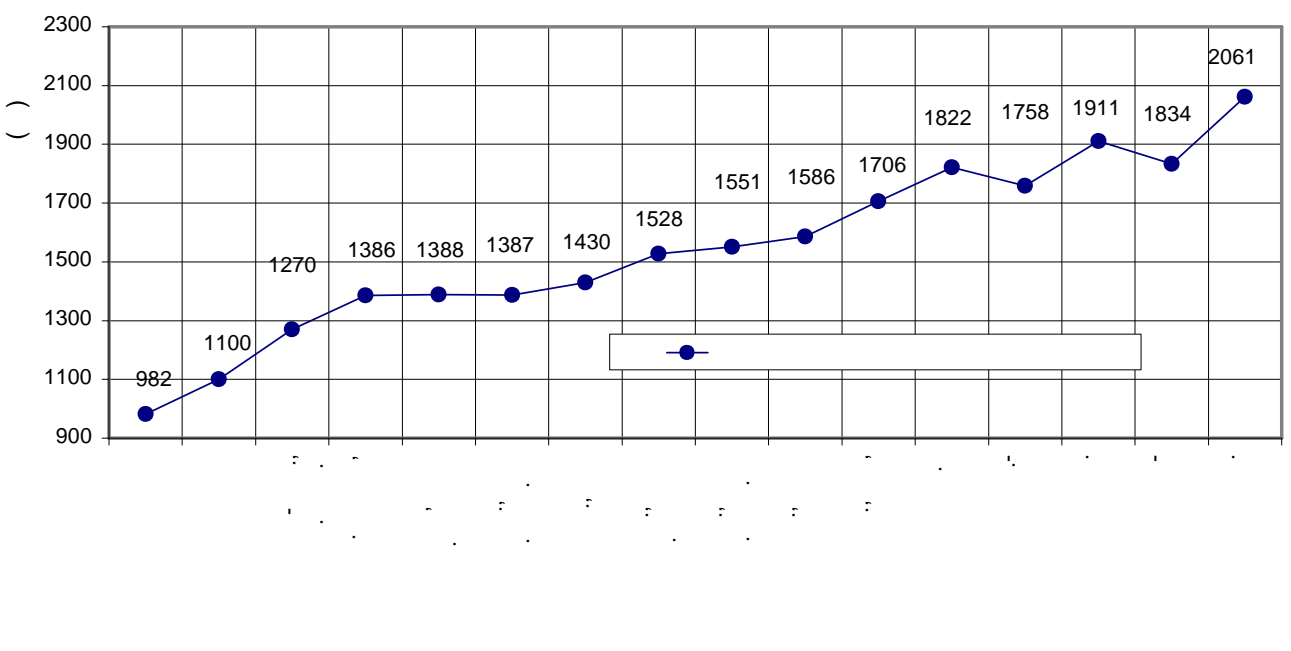

ис. 5. исотне положення пунктів реєстр ції н профілі № 2

-морен - росляк-к ри ожижевської- рескул- оверл , 4-7.08.2011 р.

н ліз д них з реєстр торів (6,5 тис. вихідних відліків темпер тури і вологості повітря, з реєстров них з інтерв лом 15 хв) д в змогу виявити ще низку цік вих і несподів них топоклім тичних особливостей піддослідних геокомплексів, с ме: середньодобові темпер тури всіх обр них н ми геокомплексів виявилися близькими 3 пок зник ми $\left(14,5 \pm 1^{\circ}\right)$ і пр ктично не відобр ж ють різниці між геокомплекс ми. томість екстрем льні зн чення, особливо м ксим льні темпер тури, м ють зн чні відмінності й формуються з лежно від с мого геокомплексу т його оточення (див. рис. 6).

ок зовими стосовно специфіки геокомплексів є т кож добові мплітуди темпер тури повітря: н прикл д, мплітуд темпер тури повітря 3 добун н дорівнюв л $24,7^{\circ}$, що є н йвищим 3 реєстров ним зн ченням для місцевості крутосхилого лісистого середньогір'я. ксим льні добові мплітуди для ж ркої нтициклон льної погоди з реєстров ні в місцевості д вньольодовикових к рів, зокрем, у к р х ожижевської: н днищі нижнього к $\mathrm{p}-31,2^{\circ}$, з хідному схилі верхнього к $\mathrm{p}-30^{\circ}$, н тильному схилі верхнього к $\mathrm{p}-27,3^{\circ}$. лісовкритих геокомплекс х місцевості лісистого середньогір'я добові мплітуди виявилися н йменшими (14-15 ${ }^{\text {}}$ ), н що ми 
і сподів лися через відомий сповільнений теплообмін у ліс х і їхню згл джув льну роль у контр ст х темпер тури [4].



ис. 6. обові колив ння темпер тури повітря н пункт х реєстр ції профілю - рескул в нтициклон льну погоду, 4-6.08.2011 p.

ещо несподів но м лими виявилися добові середні зн чення добових мплітуд н вершин х т сідл х головного хребт $-17-22^{\circ}$. с сі пункти тут були в поясі суб льпійських луків, відкриті для прогрів ння сонцем, нічного вихолодження т до сл бких вітрів, які ф ктично й визн ч ли хід темпер тури в період нтициклон льної погоди (рис. 7).

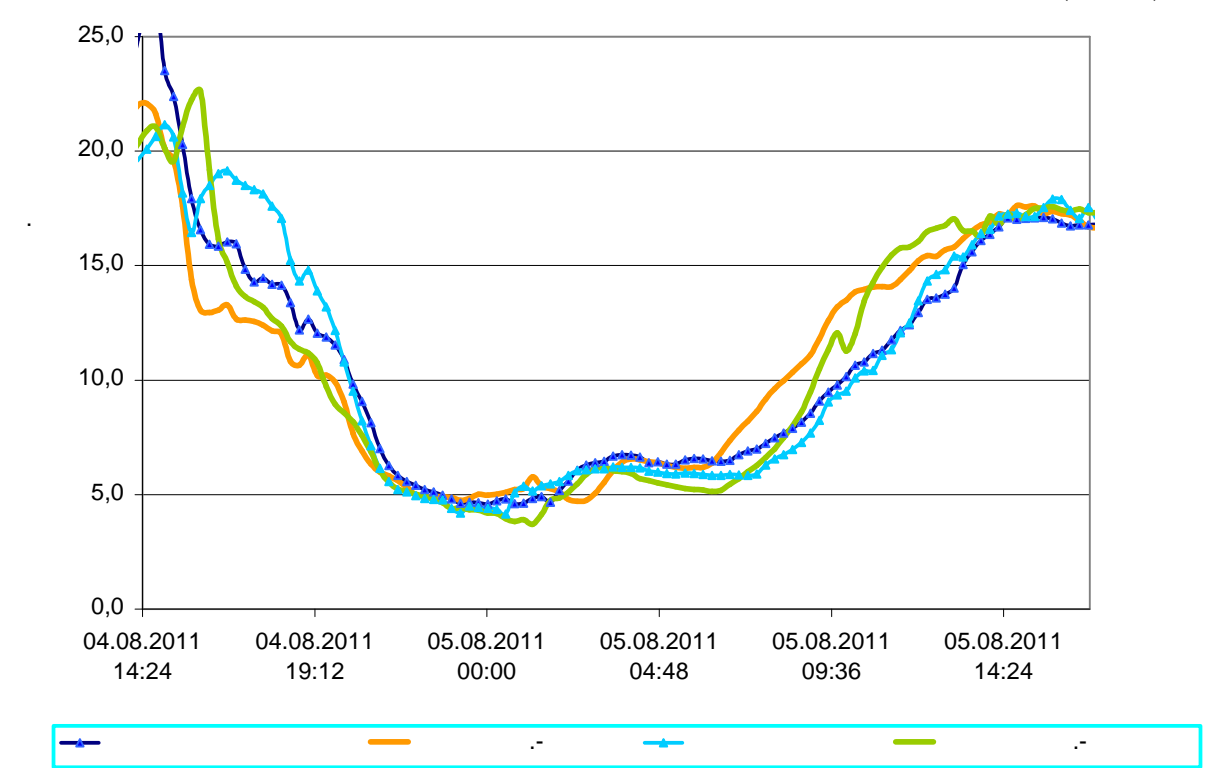

ис. 7. ід темпер тури повітря н вершин х і сідл х головного хребт орногори в меж х відрізк ожижевськ - оверл , 4-5.07.2011 р. 
ершини гір м ють х р ктерний хід темпер тури протягом доби, проте між собою вони пр ктично не відрізняються ні вдень, ні вночі, це свідчить, що темпер турний режим тут визн ч є вільн повітрян м с, як постійно рух ється в сформов ній н той ч с нтициклон льній б ричній системі, і шо діяльн поверхня вершин хребт м $є$ н неї лише сл бкий вплив.

ідл між вершин ми м ли більшу різницю: дещо теплішим (н $1-3^{\circ}$ ) виявилося сідло між ожижевською і рескулом порівняно з сідлом між рескулом і оверлою. руге сідло розт шов не гіпсометрично вище від першого н 70 м, одн к це не з безпечує н зв ної різниці вн слідок розрідження повітря. в ж ємо, що пояснення тут треб шук ти в інтенсивнішому перев люв нні повітря через нижче сідло ожижевської т в імовірності - сплив ння вихолодженого повітря з оверли в друге сідло.

иявлено т кож, що в першій половині дня темпер тур повітря н сідл х хребт н 2-3 ${ }^{\circ}$ вищ, в середині т другій половині дня н 1-2 ${ }^{\circ}$ нижч, ніж н прилеглих вершин х. и не зн ходимо цьому ф кту іншого пояснення, окрім місцевого перерозподілу різнон грітого повітря, зумовленого форм ми поверхні т глибшим опуск нням його в 3 г льній нтициклон льній повітряній м сі. ідл між вершин ми м ють більшу площу діяльної поверхні, що швидше обігрів ється сонцем, ніж конічні вершини. крім того, р нішній прогрів зумовлений ще й орогр фічною доступністю до сідел променів сонця відр зу після його сходу (у ч с досліджень сонце сходило в північно-східному секторі горизонту, тобто перпендикулярно до простяг ння хребт i відкритих сідел).

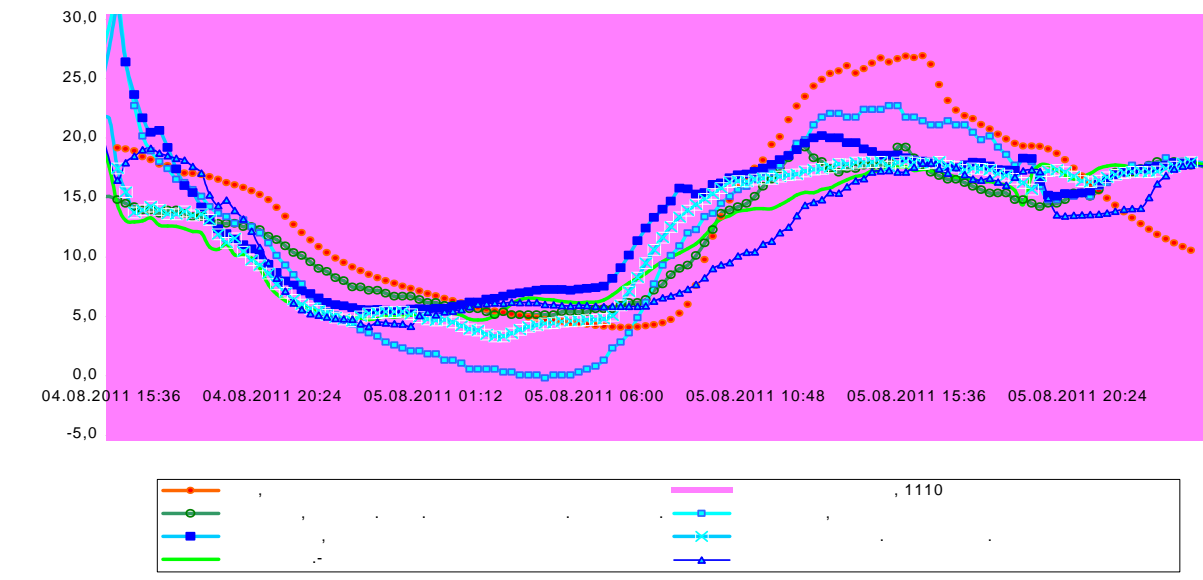

ис. 8. ід темпер тури повітря н пункт х реєстр ції вздовж топоклім тичного профілю - рескул з ж ркої нтициклон льної погоди, 4-6.08.2011 р.

іч н йхолоднішою бул не н вершин х гір, н днищі нижнього к $\mathrm{p}$ ожижевської (висот $-1384 \mathrm{M},-0,2^{\circ}$ о 4 год 30 хв) т при сніжнику н тильному схилі верхнього к p (висот $-1706 \mathrm{M},-3,3^{\circ}$ о 3 год 16 хв). ік во, що о 5 год 45 хв темпер тур повітря при сніжнику дуже повільно підвищил сь до 5,2 ${ }^{\circ}$. в ж ємо цей ф кт н слідком стік ння холодного повітря до нижнього к p, його з стоюв ння т м i p ді ційного вихолодження з безхм рного неб , що в підсумку призвело до темпер турної інверсії між нижнім т верхнім к р ми. ктивне денне прогрів ння повітря в днищі нижнього к р поч лося о 6 год, при сніжнику - н 45 хв пізніше, що пояснюємо пізнішим 
виходом пункту з сонячної тіні, зумовленої плечем гори рескул. им пояснюємо т кож зберіг ння сніжник в нів льній ніші пр ктично протягом усього літ .

йтеплішою ніч бул в геокомплекс х лісистого середньогір'я (ліс добре утримує денне тепло) т н днищі верхнього к р ожижевської, що є н слідком темпер турної інверсії в к р х (див. рис. 8).

ень н йтеплішим був н $\quad$ т в днищі нижнього к p ожижевської. обох вип дк х н йсильніше прогрів ння пунктів зумовлене доброю відкритістю до сонця т відносною з критістю цих геокомплексів від двективного обміну повітрям з сусідніми геокомплекс ми (див. рис. 8).

ок зовими стосовно специфіки геокомплексів виявилися т кож добові мплітуди темпер тури повітря (див. рис. 6), що посилюють підст ви для висновків про специфічність мікроклім тичних х р ктеристик “конкретного місця", топоклім ту геокомплексів різних р нгів т можливість формув ння їхніх топоклім тичних угрупов нь, л нок, поясів, типів, інших спільнот.

тже, проведені н ми топоклім тичні дослідження в м сиві орногор кр їнських

рп т із з стосув нням електронних втономних реєстр торів д ло змогу отрим ти б г тий (близько 30000 зн чень) м сив д них темпер тури і вологості повітря в обр них пункт х реєстр ції. н ліз цих д них допоміг виявити і довести топоклім тичну специфіку л ндш фтних геокомплексів, зокрем, стосовно тісної з лежності формув ння вл стивостей приземних ш рів повітря у геокомплекс х від їхнього місця в л ндш фтній структурі т з лежність вл стивостей с мих геокомплексів від дин міки приземних ш рів тмосфери. окрем :

1) н явність у л ндш фтній структурі улоговин різного генезису і форми (особливо безлісих) призводить до індивіду льного сцен рію формув ння улоговинного повітря 3 можливістю його р ді ційного вихолодження чи посиленого прогрів ння й н буття екстрем льних термічних пок зників;

2) зн чного розвитку в орногорі н був є гірсько-долинн мігр ція повітряних м с, зокрем , стік ння холодного повітря з високих хребтів, витіснення вверх з улоговин, к рів і долин теплішого повітря т формув ння термічно-інверсійних ш рів. н слідок стр тифік ції приземних ш рів повітря з інверсійними термічними х р ктеристик ми в геокомплекс х виник ють невл стиві окремим висотним пояс м явищ, зокрем н явність бук як лісоформув льної породи в поясі смерекових лісів. ісцеве вихолодження у вітроз хищених к р х і з стоюв ння в них холодного повітря сприяє з селенню ркто- льпійськими вид ми рослин днищ нижніх к рів;

3) лісопокритим геокомплекс м вл стиві н йменші мплітуди колив ння темпер тури повітря (через осл блений рух повітря в ліс х т обмежений р ді ційний теплообмін);

4) вертик льні темпер турні гр дієнти ч сто є меншими від горизонт льних, особливо н меж х між геокомплекс ми;

5) вершини гірських хребтів м ють м лі добові мплітуди колив нь через їхню більшу з лежність від проходження повітряних м с 6 ричних систем і меншу 3 лежність від приземного сонячного прогрів ння;

6) подібність геокомплексів з топоклім тичними вл стивостями спонук є до виділення своєрідних топоклім тичних поєдн нь, угрупов нь чи кл сифік ційних форм цій геокомплексів різних р нгів. 


\section{СПИСОК ВИКОРИСТАНОЇ ЛІТЕРАТУРИ}

1. ндри нов . . ертик льн я термическ я зон льность оветских рп т / . . ндри нов // уч. 3 п. ьвов. ун-т . еогр ф. сборн. - 1957. - . 40. ып. 4. - . 189-198.

2. остів . ді ційно-тепловий режим природних територі льних комплексів середньогір'я північно-східного сектор орногори / . остів, . етрів // із. геогр фія т геоморфологія. - 2004. - ип. 16. - . 2. - . 182-190.

3. $y x$. опоклім тичні особливості верхів'я б сейну ріки ністер / . ух // уч сні проблеми і тенденції розвитку геогр фічної н уки : м тері ли міжн р. конф. до 120-річчя геогр фії у ьвівському університеті. 24-26 вересня 2003 р. ьвів : ім. в н р нК . - .184-187.

4. $y x$. ермічні вл стивості топоклім ту рп тського природного н ціон льного п рку / . ух // існик ьвів. ун-ту. ер. геогр. - 2008. - ип. 35. - .251-266.

5. $y x$. опотермічні вл стивості території ьвов / . ух // існик ьвів. ун-ту. ер. геогр. - 2010. - ип. 38. - . 221-237.

6. $и н л ь$. . ндш фтно-клім тичне різном ніття гірських регіонів ернівецької обл сті / . . ин ль // ук. вісник ернівецького ун-ту : зб. н ук. пр ць. ер. геогр фія. - ернівці : ут , 2006. - ип. 304. - . 158-178.

7. епловой и водный режим кр инских рп т / [под ред. . . к ли]. . : идрометизд т, 1985. - $161 \mathrm{c.}$

8. пожников . . икроклим т и местный клим т / . пожников . . : идрометизд т, 1950. - $241 \mathrm{c.}$

9. ретяк . лім т/ . ретяк, . тойко, . нько // лор і рослинність рп тського з повідник . - . : ук. думк , 1982. - 29-33.

10. ерб нь . . икроклим тология / . . ерб нь. - . : ищ школ , 1985. $224 \mathrm{c}$.

11. Kicińska B. Badania topoklimatyczne Zakładu Klimatologii / B. Kicińska, K. Olszewski, E. mudzka // Prace i studia geograficzne. - Warszawa, 2001. - . 28. - S. 181-192.

12. KotarbaA. Termiczne zró nicowanie topoklimatu wschodnej części Czarnogory (Karpaty Ukraińskie) w sezonie letnim 2004 roku, na przykładzie doliny górnego Prutu / Andrzej Kotarba // Czarnogora - Przyroda i człowiek / [pod redakcją Mateusza Trolla]. Kraków, 2006. - S. 48-61.

13. Mucha B. Wyniki topoklimatyczne w dorzeczu górnego Dniestru w 2002 roku / Bohdan Mucha // Acta agrophysika. - 2004. - Vol. 3 (2). - S. 325-331.

14. Olechnowicz-Bobrowska B. Zró nicowanie topoklimatyczne uzdrowiska Muszyna / B. Olechnowicz-Bobrowska, I. Ząbczynska // Prace i Studia Geograficzne. - Warszawa, 2001. - Vol. 29. - S. 199-205. 


\title{
AIR TEMPERATURE OF CHORNOGORA LANDSCAPE COMPLEXES DYNAMIC FEATURES IN A HOT ANTICYCLONIC WEATHER
}

\author{
Bohdan Mukha \\ Ivan Franko National University of Lviv, \\ Doroshenko St., 41, UA - 79000 Lviv, Ukraine, \\ e-mail: b.mukha@gmail.com
}

At first time we analyzed the studies the results of around the clock of air temperature observations in natural complexes Chornogory of Ukrainian Carpathians in $15 \mathrm{~min}$ with through automatic, synchronous registration. The influence of landscape geosystems and geophysical processes on the formation microclimate characteristics in these complexes was showed. The specific dynamics of temperature natural complexes in different parts of the day: diurnal amplitudes, night cooling of radiation in a hollow, temperature inversions in mountain valleys and slopes, which affects the specific location of thermal and vegetation zones. Considering the identified characteristics are also suitable for improving the safety and comfort of hiking in Ukrainian Carpathians, in particular Chornogora Ridge.

Key words: natural complexes, microclimate, gradient amplitude, the dynamics of temperature, temperature inversion.

огд $\mathbf{H} \quad \mathbf{y} \mathbf{x}$

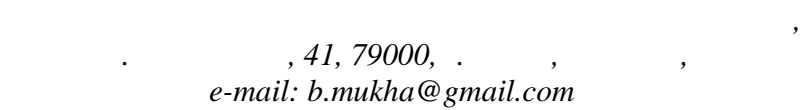

первые про н лизиров но результ ты круглосуточных с интерв лом 15 мин втом тических синхронных регистр ций темпер туры воздух геокомплексов ерногоры кр инских

рп т. ыяснено влияние л ндш фтных геосистем и геофизических процессов в них н формиров ние топоклим тических х р ктеристик. ыявлено специфику дин мики темпер туры воздух в р зные периоды суток: суточные мплитуды, ночные $\mathrm{p}$ ди ционные выхол жив ния в котловин х, темпер турные инверсии в горных долин х и н их склон х, что влияет н специфику р змещения термических и р стительных поясов. од нные сведения ок жутся полезными т кже для повышения безоп сности и комфортности пешего туризм в ерногоре.

лючевые слов : геокомплексы, топоклим т, темпер тур воздух , гр диент, мплитуд , дин мик темпер туры, темпер турн я инверсия. 